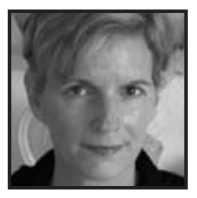

\title{
Angels, Wings, and Hester Prynne: The Place of Content in Teaching Adolescent Artists
}

\author{
Mary Hafeli, Maryland Institute College of Art
}

\begin{abstract}
From "Angels, Wings, and Hester Prynne:The Place of Content in Teaching Adolescent Artists," by Mary Hafeli, 2002, Studies in Art Education, 44(1), 28-46. Copyright 2002 by the National Art Education Association. Reprinted with permission.
\end{abstract}

\begin{abstract}
This case study uses adolescents' accounts of studio practice to trace the diverse themes, sources, and contexts that inspire aesthetic and narrative meaning in their artworks. Beyond self expression and formal and technical concerns, the study illustrates how eight young artists work to address cultural and aesthetic themes that borrow, build on, and ultimately reinvent conventional narratives and art forms. Narrative formation, and its relevance for learning and teaching art, is investigated as distinct but related practices in multiple worlds of art, cultures, and education.
\end{abstract}

"Have you ever seen Romeo and Juliet, with Claire Danes? I won this contest, I look like Claire Danes and stuff. And that's my favorite movie, I've seen it so many times. You know how she wore those beautiful wings? I wanted to make a pair for myself, and I figured out how to do it in my mixed media class."

So begins Jill, 16, talking about what prompted her "Juliet" wings, a self-initiated project carried out in an intensive, month-long summer art program for high school students. The ethereal, four-foot wide construction is made from six rows of cut, scored and fringed paper feathers, each with, according to the artist, "two coats of gesso so it's got texture and looks like a feather."

"They're so beautiful," she sighs."I can't wait to wear them to the prom next year. Can't you just see me?"1 


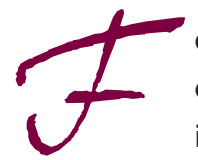

or artists, and for adolescents like Jill who take art classes in school, composing works in the studio invites the "making of aesthetic meaning" (Ross, Radnor, Mitchell, \& Bierton, 1993, p. 167). Yet, while art programs may be settings in which young people develop and express meaning, art teachers do not always teach for or acknowledge such content. Case studies of studio art instruction have found that teachers use class time to focus on technical, formal, and perceptual considerations (Ross, et al.), and to communicate personal values about what counts as success in these areas (Elkins, 2001; Rosario \& Collazo, 1981; Sevigny, 1977; Taunton, 1986). In some situations, teachers may not feel comfortable exploring interpretive issues and may avoid doing so, even when young people are willing to talk about the content and sources of their work (Hafeli, 2000). In other cases, students' source material may be viewed by their teachers as not representing "real" art content, when themes are spontaneously or repeatedly derived from media images, popular culture, or social practices found questionable by the teacher (Duncum, 1989; Wilson, 1997). For various reasons, students are often left on their own as they go about the authentic practice of working through ideas and developing narratives that figure into the content, the "aboutness" (Danto, 1981), of works done in art class.

Outside the art class context issues of content have taken center stage for a number of contemporary artists and critics, to the extent that for some, "aesthetic value" is "necessarily divorced from meaning: form and content may not coexist" (Benezra \& Viso, 1999, p. 19). But for others in the art world, formal and aesthetic issues, like beauty, have re-emerged or have remained as central concerns. The distinction between form and content has surfaced repeatedly in the history of art, with more value placed on one or the other at various times, and within various times. For some artists, separating form and content has been impossible--Ben Shahn wrote, for example, that "form is the shape of content", no more or less important than the ideas that "went into it" (Shahn, 1957, p. 72).

Like the form versus content debate, the value or legitimacy of different sources for themes and ideas in art works has been an ongoing topic of discussion for the art classroom, the art world, and, of course, the larger community. ${ }^{2}$ The history of art has shown that content can be anything and that themes and ideas thought to be "unworthy" in the past have "broken the canon" and "risen to the very heights" (Shahn, 1957, p. 72). In art education today, philosophies abound as to what constitutes appropriate content for student art work. ${ }^{3}$ And, for art teachers, the resulting debate over approaches and orientations to teaching art raises questions about how to design relevant and authentic studio experiences for students. How should con- 
tent be considered in studio teaching and in responding to students' art works? What sorts of ideas and themes do students themselves seek to address as inquirers and interpreters of the world around them, ${ }^{4}$ and as responsive, independent artists in the studio? Where do these ideas come from? What do teachers need to know about students' development of content to teach the practice of making art works?

\section{Tracing Content Origins in the Work of Adolescent Artists}

I began to explore some of these questions by talking with high school students enrolled in a state-sponsored, summer art program in New York. The purpose of the study was to identify and describe origins of adolescent art content--the sources for formal, perceptual, aesthetic and narrative ideas, themes and concerns that adolescents address through their artwork.

The summer art program was used as a case site because it draws a culturally and socio-economically diverse group of young people from high schools throughout the state. Students are selected for admission through portfolio review, and the 130 participants represent a range of studio abilities and experience--from students who have taken several studio courses and plan to attend art school to those who have not taken art courses and do not plan to pursue the study of art in college. The program offers courses in drawing, painting, printmaking, sculpture, mixed media, and interdisciplinary arts as well as courses thematically focused on the figure and landscape. Participants choose two courses to take during the four-week session, and spend several hours in each studio daily.

\section{Development and Interpretation of Field Texts}

Qualitative methods used to develop "field texts" for the study include videotaped interviews with individual students, informal conversations with program staff, and examination of student artwork. ${ }^{5}$ During the last week of the program I spoke with eight students, aged 15 to 17, in separate interviews that lasted from 45 minutes to an hour. Students were selected by the use of purposeful sampling (Patton, 1990, pp. 169-178) to achieve diversity according to gender, cultural background, socio-economic background, and art experience. Students who took part in the study live in rural, urban, and suburban areas and all attend public high schools. Two of the eight students speak English as a second language, and one recently immigrated to the United States from South America. 
Prior to being interviewed, each student assembled a portfolio of works created during the session and was asked to choose two or three recently completed pieces to talk about. Our conversations focused on these works and on the representational, symbolic, aesthetic, formal and technical considerations that the artist identified as being important to their development. Specifically, we discussed the content of the works, or what they were "about," as this was determined by students' compositional choices, their selection and handling of materials and techniques, their use of representational and symbolic images and themes, and their purpose in creating the works. We also discussed the sources of students' ideas and concerns, and the context for those sources including the art classes and lessons in which the works were created.

The interview transcripts were coded using thematic categories that emerged while reading and interpreting the data. In the separate interview texts, each statement was analyzed and coded for aspects of the work that the artist identified as contributing to its meaning, like the effects from technique by applying paint in a particular way or from formal composition by using color to create a certain ambiance. The interview texts were also coded for the sources students drew or borrowed from in developing narrative and artistic dimensions of their work, like films and TV shows they watched, books they read, experiences they had or artists' works they admired. These sources were further coded according to the contexts in which the artist placed or experienced them, such as popular or traditional culture, the art world, the local community, the school culture or educational world, and the artist's family or personal world.

\section{Content and Sources in Adolescent Artworks}

In a pooled analysis of the interviews in which 29 artworks were discussed and analyzed, 11 characteristics emerged as influences on the students' development of content (Table 1). As they described what their works were about and identified specific characteristics that contributed to these meanings, the students referred to features such as the qualities and organization of formal aspects like line, color, and value contrast. To the students, the use of contrast could lead to an accurate representation of something observed, or it could suggest a particular mood, or it could cause areas of the work to pop out or "fade gradually in the light." The students also talked about content in terms of materials and techniques. Here, the artist's selection and application of materials, like "spilling" ink and using dirt in a collage meant to "look really old", produced distinctive looks, effects, and aesthetic responses, thereby suggesting other ideas in the work. 
Within their accounts of how narrative meaning is developed, the students described some works as being about the direct observation of people and objects. In addition to visual acuity, getting a likeness through observation meant being able to portray interpreted characteristics of the model like an attitude or feeling suggested by a pose or facial expression. Working from life also involved noticing and bringing forward in the work special qualities of people, objects and materials, like the "beautiful, sheer drape" of an "elegant" woman's gown. In working from observation, the students made decisions about how far to develop different areas of the work and what to include and not include from the model and setting based, in part, on their aesthetic responses to and interpretations of observed qualities and features.

Three other modes of narrative representation came up in the students' descriptions of content. Works could be about a real or imagined event or experience, or they could be based on broader themes stemming from ideas, feelings or beliefs about issues and events that affected the artist in some way. The work could also have metaphoric content through the artist's use of symbolism, as in a painting with an "angel, who involves beauty" and a baby "who always represents innocence." Across all of these categories, in forming the narrative and artistic aspects of their work students drew from a wide range of sources and influences beyond their immediate experiences. Some incorporated ideas from stories and events and some were influenced by different aspects of artists' works--from style to subject matter to technique--that somehow related to or informed their own art work. Beyond their personal worlds students cited a variety of sources for artistic and narrative content, like books, films, news reports, television shows, magazines, comic books, and Internet sites.

For some students, aside from meanings derived from form, materials and narrative representation, artworks were also about the challenge and stimulation that came from the act or experience of doing the work. The students talked about certain drawings, paintings and constructions as documents of their developing skills and insights as artists. They described some works as revealing, for example, how the artist attempted a daunting representational challenge and succeeded, or improved technical skills by "getting the hang of" materials previously viewed as difficult or unwieldy. Content here was not just based in responses to form and technique and stories and messages; meaning was also to be gotten from viewing the work as a record of the artist's ability and knowledge.

Finally, the students identified different kinds of contexts and environments that influenced the development of artistic and narrative content in their work. Some 
Table 1:

Origins of Content in 29 Adolescent Artworks

1. Formal aspects and their effects: Specific sensory or aesthetic qualities achieved by purposeful use and arrangement of color, line, shape, value, texture, etc.

I like it because the way I did the contrast, it just sort of fades gradually in the light.

2. Art materials/techniques and their effects: Specific sensory or aesthetic qualities achieved by deliberate or experimental use of paint, ink, paper, clay, found materials, etc.

I wanted to make it look really old, like it was just lying on the ground and people would pass by it and stuff. I got the idea from the newspaper. It was old already, I just wanted to make that more apparent. So I used dirt and spilled ink on it, then used the gum and the cigarette butt and Conte crayon in other areas.

3. Representing objects/people/settings by observation: Purpose in representing objects is to get a "likeness"--visual, sensory, aesthetic, attitudinal, etc. Objects or features of the "model" may themselves be appealing, causing the artist to want to represent them.

I thought it was fun to draw because it's so cool, it has this beautiful, sheer drape sort of thing.

4. Representing real, imagined, or documented event/experience/story: Reference to or representation of narrative or happening--actual, invented, or combination of both. From personal experience, book, film, etc.

So I put a little picture of me wearing the dress I wore to my school's talent show. And the talent show meant a lot to me because I got to sing in front of all these people and I got to wear this big, long gown, and I felt so great. So I put that in.

5. Representing ideas, feelings, beliefs: Messages or meanings in works, based on experience, imagination, observation.

They give you a hint as to what I'm trying to say, like "nothing is left", and "degeneration" and everything. It's supposed to mean that people nowadays really don't care about the newspaper, like they don't care about the whole world's issues, and the news itself is not so happy. They're just confined to their own little lives. 
6. Representing ideas through symbolism: Use of form, materials, images, etc. to signify ideas, feelings, states of being.

All of these sections are different blues because of the angel, who involves beauty, and then there's the little baby who always represents innocence.

7. Development of skill: Getting better at doing something, learning a new technique or way of doing something, gaining new insight.

I wanted to do it because I'd never drawn something like that--it was hard with all those layers, how it gets darker where there's more folds.

8. Art lesson or teaching: The student's interpretation of the assignment guidelines, influence of teacher feedback within the lesson, etc.

We had to do a self portrait and put something of the past or future in it.

9. Other lesson or teaching: Learning or experiences in non-art classes.

The teacher was talking about symbolism ... and that reminded me of English class and The Scarlet Letter. That was about symbolism and secrets. So I thought I could do a movie poster that sums up the whole, entire book, and reveal the secret in a way.

10. Art world: Styles, media, content, etc. from artists and art world.

There are some artists who influence my work, like Dali. I saw these paintings of his at the Metropolitan Museum and it really fascinated me because I have, like, the same concepts, the same ideas of having dreams collide into the painting.

11. Culture--Family, Traditional, School, Local Community, Popular: People, events, practices and stories from personal, family, community, school worlds and popular culture.

Angels have been part of my whole life, since I was little. I used to hear these stories from my grandparents, which, they were just these awesome angels who helped people. 
of these are educational contexts, such as the art lesson and characteristics of the class in which the work was created, including the teacher's comments and questions about the work as it developed. Teaching or lessons outside the art class is another educational context--some students got ideas for artworks from books they had read and discussed in English class, or from research on social and political issues they had carried out in social studies class. Other contexts that the students associated with content development are the art world, where through visits to museums and galleries they were inspired by artists' works they saw, and family, traditional, school, local community, and popular cultures, where specific beliefs, practices, people, activities or events were a constant source of ideas in artwork.

The multiple features, sources and contexts identified in these adolescents' descriptions of content are not particularly surprising. As artists and studio art teachers we know that within today's art world, with its divergent justifications and sources for ideas and motivations, making works involves thinking about and responding to many of the considerations identified by the students. ${ }^{6}$ And for contemporary artists, meanings, intentions, and narratives are developed within a set of contexts or worlds that parallel those that the students describe. But how adept are we as teachers at furthering the development of all of these different facets of artistic thinking? Beyond teaching technique, beyond teaching about formal and aesthetic issues and visual culture, and beyond teaching for perceptual awareness and visual acuity, how do we teach for other essential aspects of student content? What do we know, for example, about the process through which students construct narrative and aesthetic meaning? What do we know about the stories, experiences, relationships and issues that motivate and inspire their works, and about the different worlds, beyond our lessons, that stimulate their ideas?

In the following profiles of works done by Eduardo, Jill, and Anna, these content influences are illustrated in separate processes of making a wood sculpture, a mixed-media construction, and a charcoal drawing. Eduardo's angel sculpture, Jill's wings construction, and Anna's drawing of Hester Prynne also provide a closer look at some artistically and educationally relevant sources for students' ideas that often are not addressed or go unnoticed in studio teaching.

\section{Eduardo's Angel}

Eduardo is 17 and recently immigrated to Brooklyn from his family's home in South America. He made his angel sculpture in a mixed-media class where the assignment was to "combine a toy that has moving parts" with "something that 
means art, or means something to you." The following description of the work is taken from an analytic memo I wrote shortly after our conversation at the end of the summer session.

Eduardo's favorite portfolio piece is a skeleton-like construction. It's a wood figure with head bowed down, arms cradling a small form, and an intricate, horizontal framework built onto the back. The piece is about 5 feet high, assembled from assorted lengths of scrap pine held together with nails and rubber bands. According to the artist, "it's an angel holding a baby."

Eduardo tells me he wanted to give the viewer the "feeling that you're interacting with the angel or with this piece of art." I assume that this interaction comes from the "toy" aspect of the lesson. But the piece is not exactly toy-like, at least in the light-hearted, playful sense of the word. Eduardo choreographed the action so that the viewer sets the event in motion by lifting the baby from the angel's arms and trying to steal him away from the scene. At once, the angel's head raises and her face bends down threateningly, looking, as Eduardo says, "exactly to your face." The viewer is cast as child abductor. And the powerful angel, wings raised high for flight (and fight), is meant to prevent this abduction at all costs.

Where does this story come from? I ask Eduardo if he's done other works about angels, and he tells me that many of his paintings and drawings feature this theme in one form or another. He pulls out a series of paintings, each with an angel figure. And he talks about how as a child he heard stories about "awesome" angels from his grandparents. It becomes clear as we talk that the angel is a significant figure in stories and beliefs that are infused in Eduardo's culture. But the angel is also an immediate presence in his personal life, for as we talk further I learn that Eduardo has been separated from, and has been trying to find, his own parents for quite a long time. The angel is not just a character from a story but an agent and personal guardian who, it is believed, might have prevented Eduardo's real-life separation from happening in the first place.

Eduardo's account of his sculpture (see Figure 1) illustrates several aspects of content development identified in the collective analysis; in particular, Eduardo's narrative ideas exemplify how adolescents, like many contemporary artists, chronicle and comment on both personal and cultural beliefs and identities. What is significant about the story of Eduardo's sculpture and about the ideas, sources and contexts it embodies? 
Fig. 1: Ideas and sources in Eduardo's sculpture

\section{The Artist: Eduardo}

Recently immigrated from South

America. Attends high school in

Bushwick, Brooklyn. Works primarily in painting and drawing, and much of his work is published in the student literary magazine.

\section{Personal/Family}

Like, we just grew up almost without parents.

EDUARDO'S

SCULPTURE:

So I decided to put, like, an angel holding a baby, made from pieces of wood.

\section{Culture/Family}

Angels have been part of my whole life, since I was little. I used to hear these stories from my grandparents, which, they were just these awesome angels who helped people. And they

Culture/Symbolism And they represent beauty. You know, the meaning of seeing an angel, you have an idea of beauty, a powerful thing. are good, and they are always helping the humans and stuff like that. 

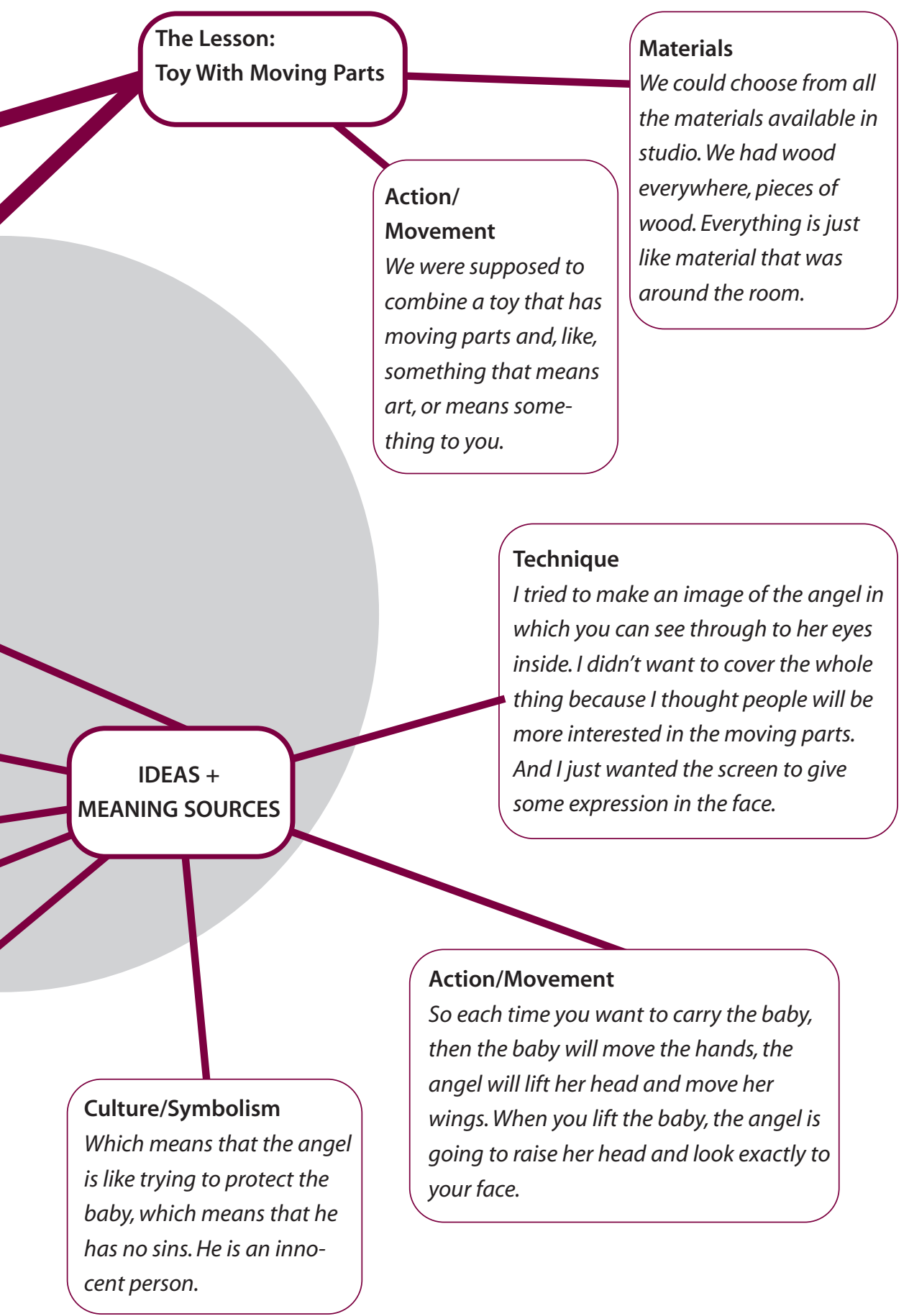
Besides the technical, formal and aesthetic issues addressed in making the angel, Eduardo plotted the dramatic confrontation set in motion by the sculpture's action. Eduardo's angel sculpture demands its viewer to physically enact a story and event created by the artist. The piece doesn't just evoke a horrifying incident, it stages one.

The story of the abduction stems from Eduardo's family experiences, and beyond this context the angel's role as protector is like that of angels who are the "guardians of individuals, especially children, and are adept at bolstering flagging courage in the face of danger" (Lange, 1991, p. 56). Eduardo described these angels as "beautiful" and "awesome" beings "who help people", and he learned about them through stories told by his grandparents in South America. This situates the characters, plot, and action of the sculpture within not only the world of the artist and his family, but also the world and narratives of his culture.

The angel sculpture, in the world of the artist and its related cultural context, is a physical version and construction of Eduardo's identity. It recounts personal actions and experiences that have helped to shape Eduardo's ideas about who he is and how he represents himself. These actions and experiences exist at the same time in a culture that

provide[s] specific types of plots for adoption by its members in their configuration of self. These plot outlines are carried and transmitted in the culture by mythic stories and fairy tales, by tales of heroes, and by dramatic constructions. Although the content of each life is unique to a person, it can share the characteristics of a general plot outline. (Polkinghorne, 1988, pp. 153-154)

Eduardo's "general plot outline", protection from abduction, stems from stories embedded in a traditional culture and the plot simultaneously recounts his own experience of being separated as a young child from his parents. While imagining the angel's form, choosing and working its materials, building its structure, and plotting its dramatic themes and ideas, Eduardo borrowed from and simultaneously reconstructed a mythical account that is well known in Hispanic cultures. Beyond simply retelling a conventional story, Eduardo both composed a new version and invented an entirely new form for it. The personal and cultural roots of the story, along with the sculpture's interactive nature, give the piece an instrumental purpose. The angel, as a sculpture and a process of making the work, is more than just self-expression from the artist's world. The work creates an artistic and culturally sanctioned forum in which Eduardo, like the Japanese children and their Manga drawings in Wilson's 
(1997) analysis of children's art content, can "experiment with life's themes" and "symbolically rehearse ways to overcome difficulties" (p. 85).

The following descriptions of works done by Jill and Anna, both 16 years old, further illustrate how students form content that creates and contributes to the culture new versions of conventional narratives. Like Eduardo, Jill and Anna drew from a variety of sources to form content in their work. In contrast to Eduardo's sculpture, based in family experiences and representing a traditional cultural narrative, Jill's construction stems from dramatic literature and popular culture and Anna's drawing is based on a book she read in English class. In each of these three cases, though, narrative content can be traced to well-known plots encountered by the artist within multiple, layered contexts.

\section{Jill's Wings}

Jill is from a small, rural town in western New York. Her wings construction, described at the beginning of this paper, sprang not from a particular lesson but from the chance to "do something on my own."

Jill says she based this piece on "those beautiful wings" worn by Claire Danes in the recent Romeo and Juliet film. Carefully cut and painted feathers are layered in six, curving rows and attached to two styrofoam pieces laced together at the back. Jill says she wanted to make the work "airy", "light", "magical", and "beautiful." The piece is beautiful in its pure whiteness, layered textures, careful detail. Here and there, real feathers have been added. These flutter and wisp in the air as she straps on the wings to show how they can be worn. Jill twirls around, and dreamily talks about wearing them to the prom next year. She looks something like Claire Danes, and was "so excited" to win a look-alike contest in her town. And she loves the story of Romeo and Juliet because the main characters are "so beautiful--just the idea of being so much in love with someone that you'd risk everything to be with them."

Jill tells me that ever since she was little she's been daydreaming about "people with wings", and mermaids. The Little Mermaid was her favorite movie and her favorite book was about Gwynna, a girl who grew wings. "So I was always swinging between having wings or having, like, fins. You know, something that changes you, makes you different from everyone." She says she'd like to make "a whole series of wings--big, giant ones--natural, brown, speckled ones--all different kinds for different reasons." 
Fig. 2: Ideas and sources in Jill's construction

\section{The Artist: Jill}

Attends high school in rural, western New York, has taken 2 drawing/ painting courses. Likes singing and being on stage. Likes drawing figures, portraits and still life from observation.

\section{Identity--Popular Culture}

I won this contest--I look like Claire Danes and stuff.

\section{Film/Lit./Popular Culture}

Have you ever seen Romeo and Juliet, with Claire Danes? That's my favorite movie. I don't even know how many times I've seen it.

JILL'S SCULPTURE

I wanted to do wings

for the prom next year. I found them in the store and they were like $\$ 80$. And I thought, 'Well, I could try making them.'

\section{Film/Lit./Popular Culture}

I've always loved, ever since I was little--The Little Mermaid was my favorite movie, and my favorite book was this story where this girl had wings. So I was always either swinging between having wings or having, like, fins. 


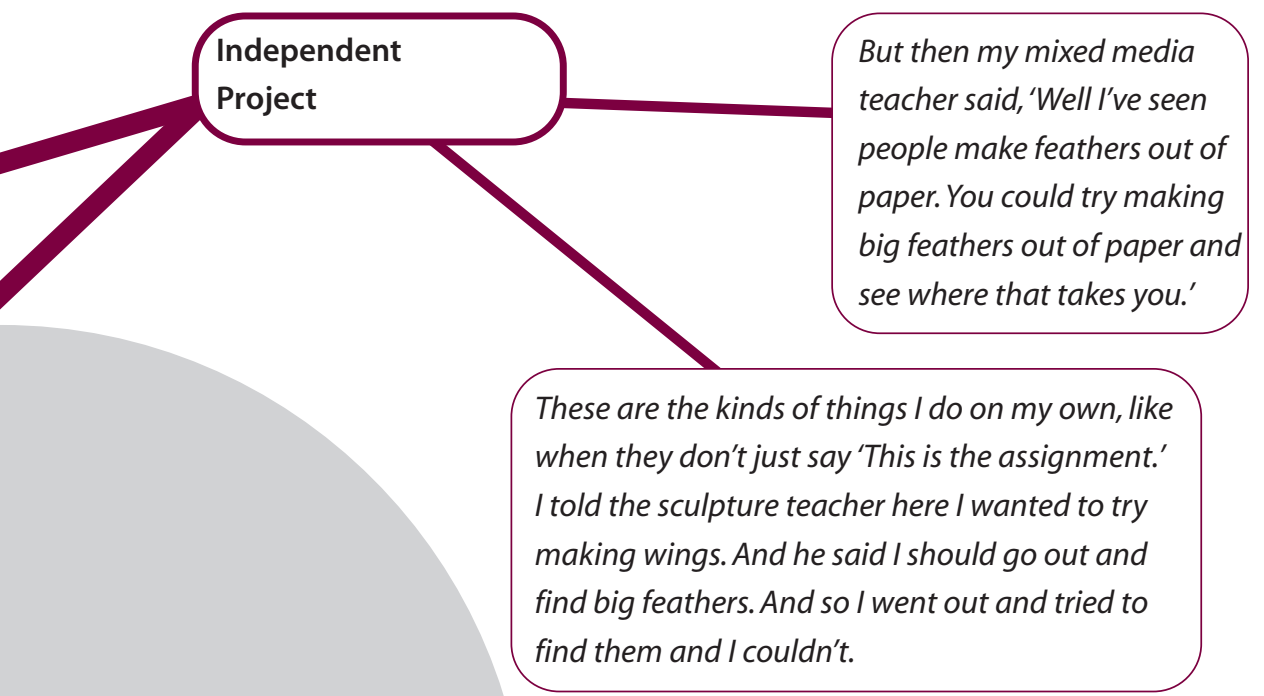
Technique/Form
I took big pieces of paper and cut them into slices and I took an Exacto knife and cut all the little chunks out to make them look feathery. Then I gessoed them all. Each one has, like, two coats of gesso, so it's got texture and looks like a feather. And I took all the feathers and made this foam structure and stuck the feathers in. And I put real feathers in the middle so it would be airy and light.

\section{Literature}

The story is about this girl, Gwynna. And her parents, you know, they can't have a child and they go to the witch woman in the woods. And so a little while goes by and they end up having a baby, but she has these little bumps on her back. And they turn into these brown wings. It's such a beautiful book.

\section{Technique}

I didn't do a great job on attaching this part. I think I need to work it out a little better before I wear it to the prom. 
Jill's construction is built around a 16-year-old girl's ideas about beauty and being beautiful, transformation, and forbidden love. Meant not just to look at but to wear, Jill's wings allow the artist to take on the admired qualities of two young women who also wore them--Claire Danes, an actress with whom she closely identifies and Juliet Capulet, one of the literary world's most enduring, love-struck, and doomed young heroines. Jill's wings, and those that inspired them, are associated with "beautiful" people--Claire Danes and Juliet Capulet and Jill, herself--in magical places--a masked ball, a senior prom.

Jill's account of her work (see Figure 2) shows how narrative and aesthetic content can be strung together from distinctly varied sources and contexts. The mixed-media construction merges ideas about personal experiences and qualities, a knowing of the ways in which materials can be worked into something "airy" and "magical" and "beautiful", and an affinity for particular people, characters and stories--from popular culture, dramatic literature, and film. Jill's construction can also be looked at in relation to tales and images about wings in numerous books written for young people; here, wings signify uniqueness and difference, beauty and transformation, angels and fairies, the natural world, transportation and escape, and special abilities. ${ }^{7}$ Jill's interest in the suggestion of wings as "something that changes you" and "makes you different from everyone" comes in part from her responses to some of these books and from reflecting over time on their plots, images, metaphors, and themes.

Jill's wings construction grows out of her fascination with wings in remembered stories, her ideas about what it means to be beautiful, her identification with a well-known actress, and her captivation with a theme in Romeo and Juliet, "being so much in love with someone that you'd risk everything to be with them." Jill's wings borrow, build on and, like Eduardo's sculpture, ultimately reinvent both a form/image and its narrative meaning. They offer a new interpretation of not only what form a wing structure can take but also what the representation of wings can be about. As a response to the plot of a classic work from dramatic literature, Jill's wings also add a new voice to a culture's ongoing conversation about the meaning of the story, including the subject of forbidden love and the broader issues that surround it like family and peer loyalty, authority, prejudice, beauty, transformation, and the nature of love itself.

\section{Anna's Hester Prynne}

Ideas about loyalty, prejudice, and the nature of love are also taken up by Anna in her favorite work from the session. Anna's piece came from a drawing lesson that explored the use of symbolism as a way to "convey a secret." 
Anna's drawing is a large, arresting charcoal portrait of Hester Prynne and the Reverend Mr. Dimmesdale, the lover she refused to expose, from The Scarlet Letter. Rendered in brilliant white and intense, pitch-black charcoal, Hester and Dimmesdale confront the viewer head on. Hester stands resolute, her gaze piercing, proud. Dimmesdale stands behind her with hand pressed to heart. At the bottom center between the two figures is a small, soft rendering of Hester holding her baby Pearl on the platform at the market place. The only color in the entire piece is the infamous, glaring red " $A$ ".

This is a "very personal" drawing for Anna. She "loves" Hester because of her moral resolve--"she knew what she did and came out to take her punishment." Anna tells me that Helen, her friend from school who was the model for Hester, also "loves the book and loves Hester." Helen provided the look and gaze Anna was after--"really young-looking and confident ... and then looking across the crowd and seeing her husband for the first time." Symbolism is everywhere in the drawing--Dimmesdale "hides" behind Hester and the hand on his chest "is a symbol of guilt." Baby Pearl is left unshaded "because she's really innocent." And, of course, Hester's scarlet letter.

Anna's drawing exploits the graphic genre of the "movie poster" to, as the artist puts it, "sum up the entire book" and "reveal the secret in a way." The secret is borne by a strong, admired heroine and her "shameful" lover. With its in-yourface scale, symbolic details, and confrontational juxtaposition of dark and light, Anna's work presents an adolescent girl's ruling on vital issues of social justice and injustice, human conflict, and morality.

Anna's account of her work (see Figure 3) illustrates how adolescent artists form aesthetic content and narrative commentary from attitudes developed in educational contexts that are not necessarily related to art class. The ideas for Anna's drawing began with a discussion about secrets and symbolism in art class. As she considered ways she might present these concepts in a drawing, Anna was "reminded" of her English class and The Scarlet Letter, which is "all about secrets and symbolism."The related themes, the presence of multiple symbolic elements in the story, and Anna's strong admiration for Hester Prynne prompted her choice of the book as source material for the drawing. Anna's ideas, attitudes and beliefs about the themes and issues in the story were developed in English class, then revisited in a drawing done a year later in a summer art class. 
Fig. 3: Ideas and Sources in Anna's Drawing

\section{The Artist: Anna}

Part of a small, selective, art-based program housed in a large Brooklyn high school. Likes observational drawing, and oil painting.

\section{Personal/Literature}

This is a personal drawing for me. I love the book a lot and I'm glad I got a chance to do this.

\section{Literature/Form/Symbolism}

I shaded over both of them, but not the baby. Because I think Pearl is really innocent. She's described as this evil child but she's got nothing to do with it. So that was my intention, to leave Pearl white.

ANNA'S DRAWING:

So I was like, okay, I can do this drawing like a movie poster that sums up the whole, entire book and reveal the secret in a way.

\section{Literature/Symbolism}

Dimmesdale, he's supposed to be really shameful of what he did, and he didn't come out and take his punishment like Hester. And that's what the hand is for. Like throughout the novel he always put his hand on his chest, and that was the symbol of guilt.

Form

lomitted

Chillingworth, the composition wasn't right. This is Dimmesdale. 
While Eduardo's sculpture came from a lesson that called for the artist to assign any kind of meaning to the work and Jill's construction did not come from a lesson at all, Anna's drawing had to incorporate symbolism in revealing a secret. As in Eduardo's work, Anna's development of narrative was a requirement in the lesson. And in all three cases this kind of narrative meaning--whether officially invited through teaching or not--was reported by the students to be critical to their conceptualization and construction of the art work. Along with the more frequently "taught for" aspects of formal, perceptual and technical effects, narrative ideas, with their divergent sources and contexts, actively defined the content and process of these students' art works. Again, that narrative meaning often figures prominently in students' development of content is not unknown to art educators. But what have remained largely unacknowledged by teachers and researchers are the implications of narrative development for student learning and artistry.

\section{Recasting Narrative in Studio Teaching and Learning}

If it's true that, as James Elkins (2001, p. 28) puts it, art teachers "still devalue the intensive investigation of meaning" in student artwork, perhaps a pedagogical rationale is needed to move us from avoiding it, addressing it only superficially, or discounting it as mere "self expression" to pursuing it as a fundamental component of art teaching. How might the investigation of students' meanings for their artworks be viewed as educationally relevant? How might teachers justify instructional time spent on examining what may seem to be the more nebulous and less disciplinespecific "stuff" of students' stories?

\section{Narrative as Art Practice}

Regardless of the task structure or guidelines of the lessons that prompted them, the "favorite" works identified by the eight students in this study all featured a particular story--constructed from memories, observations and beliefs based in diverse sources and contexts. Narrative construction is an authentic practice of artists, and interpretation of meaning is a common practice among people who study artworks. While not all artists actively work to create narrative meaning and some eschew its presence in critical appraisals of their work, ${ }^{8}$ the art world is, like the high school art class, a community of interpreters of artworks.

The ideas, sources and contexts that inspired these students' narratives are not confined to adolescent art making; they can also be found in the works of 
historical and contemporary artists who explore similar interests and concerns. Jill's ideas about "beauty" can be located in current critical debate and artistic inquiry, and her fascination with wing forms and images can be linked to contemporary artworks that span a range of media and meanings. ${ }^{9}$ Anna's exploration of literary themes and moral dilemmas and Eduardo's representation of the angel can both be located in the context of an art world. ${ }^{10}$ Although these students did not explicitly draw from art world contexts, teachers who need this kind of justification to authenticate students' development of narrative content do not need to go far to find it.

\section{Narrative as Cultural Practice}

The meanings in students' works examined in this study stem from narratives based in both personal and cultural contexts. What might be learned from constructing such a narrative, and why should this practice take place in the world of schools and classrooms? Bruner (1996) writes that "a child should 'know,' have a 'feel' for, the myths, histories, folktales, conventional stories of his or her culture (or cultures)" because "they frame and nourish an identity" (p. 41). But beyond knowing the conventional stories, learning to construct narrative also allows young people to contribute to the stories of the culture as "sophisticated myth makers" themselves (Wanner, 1994, p. 30). Although art-based research substantiates the claim that adolescents can and do create sophisticated narratives (Barrett, 1997; James, 2000; Sullivan, 1989), this view of young people as authors of rich cultural texts and inventors of new art forms that embody them does not always make its way into high school studio teaching and curricula.

The three students profiled in this study each borrowed from a culture or cultures (traditional, popular, literary) in constructing narratives in their works. They adopted cultural plots (Polkinghorne, 1988) and rewrote "cultural scripts" (Finders, 1997, p. 128). But they also created new forms for these texts. Eduardo's angel, Jill's wings and Anna's Hester Prynne add and give back to the cultures that inspired them not only new versions of known stories but also new meanings for existing visual forms.

\section{Narrative as Educational Practice}

Wanner (1994), writing about adolescents' development and sharing of written narratives, has found that focusing on students' stories in teaching brings people together in knowledge and empathy. These shared experiences build classroom culture and sustain it, and the "stories in which everyone participates form a web that 
helps bind a diverse group into a functioning unit" (p. 4). Connelly and Clandinin $(1985$, p. 191) support this focus on students' stories as part of teaching:"If in our lives we are constantly constructing, reporting, and revising various narrative unities, then education should somehow draw on, develop, remake, and introduce such narratives."11 Making use of students' narratives in the studio art classroom leads to Albers and Murphy's conception of "optimum learning," where skills and techniques are taught for the purpose of students developing "self-inspired" forms and images (Albers \& Murphy, 2000, p.x). In their study of art classes in a middle school, Albers and Murphy found that neither instruction in technique nor "immersion in visual culture" were by themselves enough for optimal learning and that students learned to elaborate on techniques and skills "only if they were given the opportunity to create selfinspired artistic representations" (p. 5). The students in their study, like Jill in this one, sought out the development of skills as they were needed to further self-generated narrative content and, for optimum learning to take place, teacher feedback and instruction was provided in the context of students' narrative concerns.

If art teachers are going to teach for the development of narrative meaning as part of students' artistic thinking and learning, we're going to have to do more than nod at it when it happens. "Obviously, if narrative is to be made an instrument of mind on behalf of meaning making, it requires work on our part--reading it, making it, analyzing it, understanding its craft, sensing its uses, discussing it" (Bruner 1996, p. 41). Teachers also need to understand the many cultures and worlds that inspire students' narratives. Like the diverse sources and contexts for art ideas described in this paper, Barton and Hamilton (1997) and Freedman (1994) argue that the wider popular culture of entertainment, media and advertising influences the content of young people's artwork, and that students may be unaware of the degree to which their ideas and responses are shaped by these forces. Studio art teaching, while developing students' technical and perceptual skills, can prompt adolescent artists to look more closely at the contexts that influence their meanings, and to explore more fully the themes and ideas and forms that are potential source material for increasingly sophisticated artworks. And, in a similar vein, studio teaching can be enriched through research on adolescents' meanings for artworks other than their own, as well as from studies of how young people encounter and interpret the kinds of source material that stem from traditional and popular culture. For if these experiences are part of the content and narratives of our students' artworks, as has been shown in this study, we teachers must get to know them, ask questions of them. As Parsons (1987) writes about our experience of artworks, "such questioning is important because the meanings of things change and cannot be taken for granted" (p. 150). 
Those who influence the artistic thinking and learning of young people should also consider photographer Vik Muniz's thoughts about artworks--"the end result is just the beginning of a narrative that moves back in time" (Solomon, 2001, p. 16). How well did I do in inviting and helping this student to shape a compelling artistic narrative? How do I understand and teach the craft of fashioning ways and forms and materials to say things? How did I take notice of this student's stories and incorporate them into the fabric of our class?

\section{Notes}

This study was conducted at the New York State Summer School for the Arts, Visual Arts Program, at the State University of New York at Brockport.I thank Randy Williams, Artistic Director, and Kevin Klein, Assistant to the Artistic Director, for their help in facilitating my visit to the program.

1. Throughout this paper, data from students are excerpted from field notes, interview transcripts, and analytic memos based on these documents. All names given for students are fictitious.

2. As I was writing this paper, the then Mayor of New York, Rudy Giuliani, declared that the First Amendment is not absolute. Following a controversy over Renee Cox's photograph Yo Mama's Last Supper at the Brooklyn Museum, on April 3, 2001 Mayor Giuliani appointed a panel of 15 men and 5 women to formulate "decency standards" for art in the majority of New York City museums.

3. These publications highlight some of the voices within an ongoing philosophical debate about rationales for teaching art, approaches to teaching art, and content of student art work: Richard Siegesmund's tracing of historical justifications and their presence in current dialogue (Siegesmund, 1998); Brent Wilson's multiple interpretations of "child art" (Wilson, 1997); Anna Kindler's description of the value of sensory and aesthetic engagement with art works (Kindler, 2000) and David Pariser's response to this paper (Pariser, 2000); and papers presented in these edited journals and books--Studies in Art Education (Parsons, 2000), Journal of Multicultural and Cross-Cultural Research in Art Education (Stuhr, 2000), and Real World Readings in Art Education (Fehr, Fehr, \& Keifer-Boyd, 2000). 
4. Although not the focus of this study, recent phenomenological inquiry into how people understand artists' works, and visual culture, provides a related context for tracing content ideas and sources within personal acts of art making. For examples of this work see Parsons (1987), Csikszentmihalyi \& Robinson (1990), Staniszewski (1995), Bosch (1998), and Freedman \& Wood (1999).

5. Clandinin and Connelly (1998, pp. 161-162) distinguish between "data"--such as field notes and photographs--and "field texts". Field texts are "selectively chosen from field experience and thereby embody an interpretive process." The authors point out that "researcher relationships to ongoing participant stories shape the nature of field texts" by "embedding meaning and imposing form" on them. My relationships to the participant stories in this study are based on insights about my own ways of working in the studio, an understanding of research and theories regarding the studio processes of artists and young people, my experiences with students as an art teacher, and the synthesis of all of these roles in my status as interested visitor in the summer art program.

6. Robert Aktins (1997, p. 79) describes content as "subject, form, material, technique, sources, socio-historical context, and the artist's intention (though the artist's interpretation of the work may be different from the viewer's)."

7. Amazon.com currently lists 177 books for young readers with the word wings in the title, each features wings as a significant image, symbol, metaphor, and/or prop.

8. John Currin, a painter: "Figuration has taken on the burden of always having to mean something, but what I think ruins a lot of painting is the urge to put meaning into it. With the nude, I managed to avoid doing that, and preserved a kind of mystery. I like that the painting ended and I never did find out what it was about." (Fineman, 2001, p. 32)

9. For critical discussion of beauty in the contemporary art world, see Uncontrollable Beauty: Toward a New Aesthetics (Beckley, 1998); Sticky Sublime (Beckley, 2001); Regarding Beauty: A View of the Late Twentieth Century (Benezra \& Viso, 1999); Beauty and the Contemporary Sublime (Gilbert-Rolfe, 2000); and The Invisible Dragon: Four Essays on Beauty (Hickey, 1994). For examples of wings in contemporary artists' works see Kiki Smith's Trinity/Heaven and Earth, Butterfly, and Bat (2000), and Emma and Melancholia (1999); Betye and Alison Saar's House of Gris Gris (1990); and Anselm Kiefer's Buch mit Flugeln/Book with Wings (1992). 
10. In the past century, angels have been featured in the works of such artists as Marc Chagall, Max Ernst, Andy Warhol, and Anselm Kiefer, filmmakers like Frank Capra and Wim Wenders, and folk artists such as Howard Finster and Purvis Young. The angel as icon, or santo, is especially prevalent in religious art created in Hispanic cultures. In Puerto Rico, the term santos applies to wood carvings of Roman Catholic saints and angels. These works are meant for private contemplation. They are "signs of the holy," the "visible embodiment of an invisible supernatural presence" and as such they "evoke the divine or saintly being they represent." (Lange, 1991, p. 49) Santos do not need to be richly decorated to evoke the saints and angels they signify. They are usually, like Eduardo's angel, constructed and finished using what is at hand such as scraps of wood, tin, paper, and other cast-off materials.

11. Connelly and Clandinin examine the teacher's potential for helping students to reflect "on the aesthetics of their personal experience." "For us, the going back over an experience and heightening a dimension is a 'giving back' of the experience, aimed at the seeing of an experience in new lights" (1985, p. 192).

\section{References}

Albers, P., \& Murphy, S. (2000). Telling pieces: Art as literacy in middle school classes. Mahwah, NJ: Lawrence Erlbaum.

Atkins, R. (1997). Art speak (2nd ed.). New York: Abbeville Press.

Barrett, T. (1997). Talking about student art. Worcester, MA: Davis.

Barton, D., \& Hamilton, M. (1997). Local literacies: Reading and writing in one community. London: Routledge.

Beckley, B. (Ed.). (1998). Uncontrollable beauty: Toward a new aesthetics. New York: Allworth Press.

Beckley, B. (Ed.). (2001). Sticky sublime. New York: Allworth Press.

Benezra, N., \& Viso, O. (1999). Regarding beauty: A view of the late twentieth century. Washington, DC: Hirshhorn Museum and Sculpture Garden.
Bosch, E. (1998). The pleasure of beholding. Barcelona: ACTAR.

Bruner, J. (1996). The culture of education. Cambridge, MA: Harvard University Press.

Clandinin, D., \& Connelly, F. (1998). Personal experience methods. In N. Denzin \& Y. Lincoln (Eds.), Collecting and interpreting qualitative materials (pp. 150-178). Thousand Oaks, CA: Sage.

Connelly, F., \& Clandinin, D. (1985). Personal practical knowledge and the modes of knowing: Relevance for teaching and learning. In E. Eisner (Ed.), Learning and teaching the ways of knowing (pp. 174-198). Chicago: National Society for the Study of Education.

Csikszentmihalyi, M., \& Robinson, R. (1990). The art of seeing. Malibu, CA: J. Paul Getty Museum and Getty Center for Education in the Arts. 
Danto, A. (1981). The transfiguration of the commonplace. Cambridge, MA: Harvard University Press.

Duncum, P. (1989). Children's unsolicited drawings of violence as a site of social contradiction. Studies in Art Education, 30(4), 249-56.

Elkins, J. (2001). Why art cannot be taught. Urbana, IL: University of Illinois Press.

Fehr, D., Fehr, K., \& Keifer-Boyd, K. (Eds.). (2000). Real world readings in art education: Things your professor never told you. New York: Falmer Press.

Finders, M. (1997). Just girls: Hidden literacies and life in junior high. New York: Teachers College Press.

Fineman, M. (2001, October 28). Married to each other, to art and to art history. The New York Times, pp. 32-33.

Freedman, K. (1994). Interpreting gender and visual culture in art classrooms. Studies in Art Education, 35(3), 157-170.

Freedman, K., \& Wood, J. (1999). Reconsidering critical response: Student judgments of purpose, interpretation and relationships in visual culture. Studies in Art Education, 40(2), 128-142.

Gilbert-Rolfe, J. (2000). Beauty and the contemporary sublime. New York: Allworth Press.

Hafeli, M. (2000). Negotiating "fit" in student art work: Classroom conversations. Studies in Art Education, 41(2), 130-145.

Hickey, D. (1994). The invisible dragon: Four essays on beauty. New York: Distributed Art Publishers.

James, P. (2000). Working toward meaning: The evolution of an assignment. Studies in Art Education, 41(2), 146-163.

Kindler, A. (2000). Art education outside the search for deep meaning: Sometimes what matters is on the surface. Art Education, 53(1), 39-43.

Lange, Y. (1991). Santos de Palo: The household saints of Puerto Rico. The Clarion, 16, 43-65.

Pariser, D. (2000). Letter to the editor. Art Education, 53(4), 5.
Parsons, M. (1987). How we understand art. Cambridge: Cambridge University Press.

Parsons, M. (Ed.). (2000). Studies in Art Education, 41(4).

Patton, M. (1990). Qualitative evaluation and research methods ( $2^{\text {nd }}$ ed.). Newbury Park, CA: Sage.

Polkinghorne, D. (1988). Narrative knowing and the human sciences. Albany, NY: State University of New York Press.

Rosario, J., \& Collazo, E. (1981). Aesthetic codes in context: An exploration of two preschool classrooms. Journal of Aesthetic Education, 15, 71-82.

Ross, M., Radnor, H., Mitchell, S., \& Bierton, C. (1993). Assessing achievement in the arts. Buckingham, England: Open University Press.

Sevigny, M. (1977). A descriptive study of instructional interaction and performance appraisal in a university studio art setting: $A$ multiple perspective. Unpublished doctoral dissertation. The Ohio State University, Columbus.

Shahn, B. (1957). The shape of content. Cambridge, MA: Harvard University Press.

Siegesmund, R. (1998). Why do we teach art today? Conceptions of art education and their justification. Studies in Art Education, 39(3), 197-214.

Stuhr, P. (Ed.). (2000). Journal of Multicultural and Cross-cultural Research in Art Education, 18.

Solomon, D. (2001, February 11). Ars brevis: Vik Muniz explains how--and why--he makes art from the most fragile media in the world. The New York Times Magazine, p. 16.

Staniszewski, M. (1995). Believing is seeing. New York: Penguin Books.

Sullivan, G. (1989). Curriculum in art education: The uncertainty principle. Studies in Art Education, 30(4), 225-236.

Taunton, M. (1986). The conveyance of aesthetic values during art activities in grades one through three. Arts and Learning Research, 4(1), 56-63.

Wanner, S. (1994). On with the story: Adolescents learning through narrative. Portsmouth, $\mathrm{NH}$ : Heinemann. 
Wilson, B. (1997). Child art, multiple interpretations, and conflicts of interest. In A.Kindler (Ed.), Child development in art (pp. 81-94). Reston, VA: National Art Education Association.

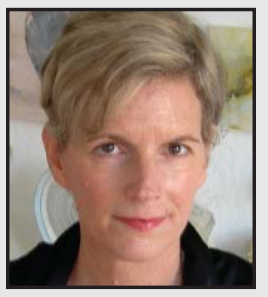

Mary Hafeli is Director of the Master of Arts in Teaching program at Maryland Institute College of Art and teaches courses in art and human development, investigations of studio materials for teaching, and qualitative research. She has won the Mary Rouse Award from the National Art Education Association Women's Caucus (2006) and the Marilyn Zurmuehlen Award for Research in Art Education (2005), also from the NAEA. She has served on the editorial board for Art Education (2002-2006) and as Chair of the NAEA Research Task Force on Student Learning (1999-2002). She received a B.F.A. in studio art from the University of Michigan, and Ed.M. and Ed.D. degrees from Teachers College, Columbia University. 